\title{
The effort of partnership: Capacity development and moral capital in partnership for
}

\section{mutual gains}

\begin{abstract}
The article discusses the enactment of a strategic partnership undertaken by a large, multi-site company and several trade unions. The enterprise aimed to institute highly engaged practices of employee and management voice to create a collaborative culture throughout the organization. The study finds that five years since the inception of the project of institutional change considerable challenges to its embedding and effectiveness remain. It also finds that particular characteristics of the partnership propose resource generation for addressing those challenges and progressing collaborative relations to mutual benefit. Substantive actor effort and organizational learning generate capacity for new relationships. That includes activation of moral capital including toleration, patience, mutual respect, reciprocity, and trust.
\end{abstract}

Key words: labour-management partnership, unions, mutual gains, moral capital

\section{Introduction}

A recurrent feature of company strategic initiative in liberal market economies is the undertaking of labour-management partnership relations. These occasional and persistent occurrences are undertaken, despite their well-known fragilities (Danford and Richardson, 2016; Geary and Trif, 2011; Johnstone and Wilkinson, 2017), for reasons typically to do with improving employment relationships and organizational life, and generating mutual gains. Research has elaborated on the many fissures, obstacles, tensions and challenges of partnership in its various guises, and analysed factors in their failure. Questions over how they are sustained over time are plentiful. Knowledge of the efforts required to navigate the 
challenges of partnership and to craft aspirations into productive relations and concrete outcomes for mutual and distributed benefit remains sketchy.

This article discusses an empirical study of an enterprise-level initiative to substantively reform industrial relations and organizational culture in a large corporation. The corporation, based in New Zealand, took an initiative to form, as declared by its charter, a 'strategic partnership' between the company and its major trade unions with intention to institute extensive and unprecedented practices of con-joint employee and management voice. The partnership undertaking aimed to forge institutional change, both of formal structures and normative habits, and create a 'collaborative culture throughout the organization'.

The article principally focuses on developments in the programme of institutional change five years after its inception. Its principal contribution to advancing debate in partnership and employee participation research fields is the identification of key characteristics of the enactment of the partnership. Those characteristics, in addition to robust formal structures for employee and management participation, are the qualitative resources of actor effort to generate capacity through developing new skills and activating moral capital (including toleration, patience, mutuality, and trust). Corporate (management and labour) learning, actor relational and identity shifts, and deployed moral capital generate new collective capacities. These propose substantive resources to embed institutional change, both formal and normative, and sustain and evolve the partnership over time. The article is structured as follows: we review key debates on partnership and collaboration, outline the particular case context, and describe the empirical study. We then discuss its findings and analysis. Further remarks are made in conclusion.

\section{Partnership debates}

Efforts to pursue labour-management collaboration or partnership relations in AngloAmerican countries have been observed over many decades (Blumberg, 1968; Lansbury, 
1980; Ramsay, 1977). A distinct turn toward partnership undertakings occurred in the 1980s and 1990s that sought a 'high road', of 'high involvement' and 'high performance' management and employee practices that would promote an organizational culture of 'continuous improvement' (Boxall and Macky, 2009; Godard, 2004; Ramsay, Scholarios and Harley, 2000; Wood, 2010) and produce diverse benefits for employees and companies. The collaborative and high performance approach to company-level management and employee relations grew out of recognition of 'mutual gains' that were afforded by developments in post-Fordist, advanced technological and production systems (Batt, 2004; Kochan and Osterman, 1994; Kochan et al. 2009; Patmore and Golan, 2003). These post-Fordist, less rigid production systems potentially required, or enabled, more collaborative team-working among workers and management (Heckscher, 1988; Hirschhorn, 1988; Wallace, 1989).

These promising prospects in the 1990s for the mutual gains of improved employment relations, high performance work practices, more congenial organizations, and productivity benefits resulted in mixed outcomes. Some found that mutual benefits include improved company productivity and performance, greater job security, and improved trust between management and employees (Bray, Macneil and Stewart, 2017; Cutcher-Gershenfeld, Brooks, Mulloy, 2015; Glover, Tregaskis and Butler, 2014). Critics pointed to disappointing results that question claims to superior outcomes of high performance systems for workers (Badigannavar and Kelly, 2011; Godard, 2004; Thompson and van den Broek, 2010). Nonetheless, the notion of high performance systems continues to influence recurrent efforts among company and labour actors to embark on projects of formalized partnership relations for mutual benefits.

Partnership essentially recognizes shared areas of interests among the parties in addition to conflicting interests. The concept generally conveys, at minimum, a sense of mutual legitimation, commitment to cooperative process, consultation, and participation. Ventures in 
partnership relationships range from modest expressions of cooperation, consultation and information sharing, to employee stock options, and provision for degrees of co-participation in high level decision-making (Ackers and Payne, 1998, Appelbaum and Hunter, 2005; Danford, Richardson, Stewart, Tailby and Upchurch, 2005; Kochan et al. 2009). Partnership is widely acknowledged to be difficult to sustain. Researchers point to their 'potential and precariousness' (Kochan et al. 2008) and document successes, failures and mutations of partnerships (Johnstone et al. 2009; Kochan et al. 2009; Stuart and Martinez Lucio, 2005; Townsend et al. 2014). Researchers find some partnerships 'resilient' (Butler et al., 2011) and of 'substantive benefit' to companies, management, unions, and employees (Geary and Triff 2011; Johnstone, 2015; Kochan, 2016).

Partnerships may enable unions to advance their institutional centrality and legitimacy claims for industrial democracy and collaborative participation (Ackers and Payne, 1998; Haynes and Allen, 2001). They may forge a 'modernisation' of employment relations to include integration of labour into employer decision-making processes (Deakin, Hobbs, Konzelmann, and Wilkinson, 2005; Dobbins and Gunnigle, 2009; Martinez Lucio and Stuart, 2002). Partnerships may be depicted on a spectrum of 'robust' to 'shallow' (Oxenbridge and Brown, 2002) in which variable outcomes are dependent on multiple factors in companyspecific configurations (Deakin, et al., 2005; Dobbins and Gunnigle, 2009; Johnstone and Wilkinson, 2017). Johnstone and Wilkinson's (2017) longitudinal study documents factors that assist partnership durability even in the highly liberalized and financialized economy of the UK. In addition to favourable conditions, those factors notably include 'strong informal relations' between union and management actors and recognition of union legitimacy.

Still others conclude that partnerships 'cannot work' (Danford and Richardson, 2016) and mutual gains are 'an illusion and figment of aspirational theoretical imagination' (Dobbins and Dundon, 2017, p. 520). Partnership, some contend, is a project of HRM that 
integrates employees into management controlled strategies and exploits their willingness to express voice (Taylor and Ramsay, 1998; Danford, et al., 2005). For labour interests, many see little prospect for partnership efforts beyond a 'faithless realism' (Stuart and Martinez Lucio, 2005) of reluctant compliance with a managerial overture to a co-opted partnership that is of more benefit to employers than employees (Guest and Peccei, 2001). Some regard partnerships in the UK as 'substantially hollow' and 'procedurally biased' (Samuel and Bacon, 2010) in large part due to a low trust culture. Some researchers advocate instead for re-invigorated trade unions and muscular industrial relations (Badigannavar and Kelly, 2011; Getman, 2010).

Others note that even where conditions are more favourable to partnership undertakings, favourable winds are not enough. Cooperative relations for mutual benefit, researchers note, take effort (Bélanger and Edwards 2007; Geary and Triff, 2011), although what comprises that effort is left unsaid. Likewise, some researchers highlight the important role of the 'quality of relations' between parties in making partnerships work (Geary and Triff, 2011; Johnstone and Wilkinson, 2017), with little elaboration about specific qualities, how they are developed, and what they yield. Some researchers argue that cooperative relations are most robust when a pluralist approach is recognized and respected. Specifically, when a neopluralist (Ackers, 2014) or collaborative pluralist (Bray, Budd and Macneil, 2015) approach is adopted, all parties recognize mutual legitimacy and conflicting interests. Parties take responsibility for addressing each other's interests and seek to find common ground and common interests (Bray et al., 2017).

\section{The New Zealand context}

In New Zealand, a long history of periodic efforts for forms of industrial democracy and employee participation has resulted in various arrangements. Building on earlier efforts for industrial conflict resolution, notably compulsory industrial arbitration and conciliation 
(Barry and Wailes, 2004) and workers' rights (that include New Zealand's early introduction of the 40-hour week in 1935) notable developments include efforts for works councils and joint consultative committees alongside collective bargaining (Boxall et al., 2007; Haynes, Marchington, Boxall, 2007; Rasmussen, 2009). A 1989 Inquiry into Industrial Democracy in New Zealand recommended introduction of formal works councils for companies employing 40 or more workers. That formal institutionalisation did not occur but voluntary participatory arrangements have been officially encouraged by successive governments over decades (Rasmussen, 2009). Recent health and safety at work legislation places a duty on non-exempt employers to implement practices of worker participation with respect to health and safety (Farr, Laird, Lamm and Bensemann, 2019). A number of employers and unions have endeavoured to institute substantive employee participation in organization decision-making. But trade unions have typically favoured collective bargaining as the predominant form of industrial participation.

New Zealand companies are relatively small with few multi-divisional operations. A majority of workplaces practice forms of joint consultation arrangements typically known as joint consultation committees (Boxall et al., 2007). Workplace reform that includes labourmanagement partnership undertakings have periodically been promoted by government programmes (Delaney and Haworth, 2016; Haynes and Allen, 2001; Macneil et al., 2011). Partnership undertakings have utilized elements of productivity bargaining and workplace modernization prominent in the US partnership model while at the same time exhibiting features of the 'social partnership' concept advocated in many European countries in which unions are recognized as contributing to the social regulation of labour markets (Huzzard et al, 2004; Macneil et al. 2011). These undertakings have resulted, as elsewhere, in a mixture of successful interventions as well as persistent problems in their consolidation (Haynes et al., 2005; McAndrew et al., 2010). McAndrew (2006) finds that where collective bargaining 
relationships are respected and 'mature' partnership relations with employees, unions and firms are more likely to be successful. Delaney and Haworth (2016) find, that despite the persistent recurrence of partnership efforts in New Zealand, they generally end in failure, overcome by the 'bleak environment' of their macro-political context. Nonetheless, labourmanagement partnership undertakings, which are costly at inception, persist in New Zealand.

\section{Research context}

We undertook a field study from late 2016 to mid-2018 of a New Zealand company that has entered into a formal partnership between management and trade unions. The company, which we refer to as Company A, operates in the transportation and freight sectors and trades in a global market. The company has been in operation for many decades and employs over 10,000 workers. Four unions represent over $70 \%$ of the workforce, and in some areas of the business nearly all employees are union members. Collective bargaining is widely accepted and commonplace. In earlier decades, prior to the sweep of neo-liberal reforms in the 1980s in New Zealand, the company had a more engaged and participatory style (including union representatives on executive committees and the company board). But the intervening decades had been marked by strife and conflict. After a prolonged period of industrial conflict, in 2013 the company and unions agreed to embark on a path toward 'strategic partnership' that entailed a programme of institutional reform throughout the organization. A new CEO, familiar with US partnership efforts, sought a new industrial relations orientation in the company.

Company documents report that management's approach to decision making prior to the partnership venture was unilateral with little meaningful employee involvement. Its style was to 'control rather than collaborate with employees' (Internal case study document). The company reported that it was poised to 'take advantage of favourable market conditions' but it was 'restricted by the deteriorating employment relationships'. Company leaders declared 
their desire for new ways of working with their workforce and changes to their conventional employment relations practices. Key union actors expressed their fatigue with adversarial relations and wished to experiment with more effective forms of influence.

With the assistance of consultants who have previously worked on the Kaiser Permanente Labour Management Partnership (see Kochan et al, 2009 and Kochan, 2016 for detail), the company and unions agreed to 'collaborate on how to collaborate'. In 2015, senior executives and union leaders of the four largest unions signed a charter that formally outlines the vision, objectives, and governance structure of the partnership intended to 'achieve mutually beneficial outcomes'. We use the pseudonym 'HIP' (high involvement and performance) to signify the particular partnership undertaking.

The parties agreed to a number of aspirations including 'meaningful employee involvement' in substantive problems and decisions, using interest-based problem solving rather than adversarial processes for disputes and disagreements, creating an environment of trust based on transparency, and that the company 'respects and supports the role(s) of unions in the workplace'. The charter lists a number of 'equally important' objectives that the company and the unions are jointly committed to developing, such as superior productivity, shareholder value, competitive position, superior wages, security and conditions, training and development, and health and safety. A new joint governance structure was introduced in order to provide a strong foundation to implement and sustain the necessary structural and behavioural changes. The company established a distinct ER function tasked with creating a more relational approach toward employees and unions.

The new structure established several layers of teams and working groups to provide respective governance, leadership, involvement and implementation functions of HIP across the company's business units. Senior union and company leaders, as well as middle managers, union delegates and front line employees are represented in the new governance structure. 
The joint structure aims to popularize the concept of collaborative partnership among former adversaries, to involve a majority of occupational groups in problem-solving, and to disperse their newly conjoint decisions on reforms and innovations through the company. By mid-2018 more than 200 issues have been addressed through HIP joint forums and agreement reached on resolutions. These range from regional restructuring, new operations systems, and technological developments, to work shift scheduling, health and safety initiatives, remuneration, and workload allocation. The partnership appears to be holding. Therefore, what are the key factors in its development and sustainability?

\section{Research design}

The qualitative field study, undertaken over eighteen months in 2016 through 2018 , utilised participant observation, semi-structured interviews and document analysis. The second author attended on-site team meetings and training events as well as off-site dissemination events. We interviewed a total of 43 participants including company managers $(\mathrm{N}=10)$, trade union leaders and workplace actors $(\mathrm{N}=26)$, and political actors and consultants $(\mathrm{N}=7)$ involved in developing and enacting the partnership and HIP. Several key company, union and consultant actors were interviewed both formally and informally on multiple occasions. We studied company and trade union documents including the partnership charter, review reports, presentations, training materials, press releases, newsletters, annual reports, and media reports. Interview questions were tailored for the respondent groups. Most people in the company refer to the partnership undertaking simply as 'HIP'. We therefore used that term in our interviews and conversations. We sought responses oriented on general questions: How is the HIP intervention being enacted/ working out? What are the main outcomes? What are the key challenges and tensions? Where are things headed? Interviews were typically of 60 minutes duration, and were audio-recorded and transcribed. 
Both authors read and coded the data based on the guiding research interest framing this inquiry. After multiple iterations of reading and discussing the data we identified themes and proceeded to collate the data based on these. We note first that respondents reported numerous tensions, obstacles and frustrations, along with accomplishments, learnings and aspirations in the practical enactment of the institutional reform venture. We were especially interested in how actors responded to persistent challenges and exasperations. A first phenomenon we identified from the data was that of actors' effort to forge an effective, concrete partnership. We focus particularly on the direction and application of that effort which we identify as the theme of capacity development. The second theme is the activation of the resource of moral capital.

\section{Empirical findings}

We state first a summary paragraph of reported generally agreed accomplishments. Managers, union representatives, employees, and company consultants reported a set of significant initial outcomes of the HIP intervention within its first five years. Most notably these are: mutual recognition and legitimacy of conflicting as well as common interests, cessation of industrial conflict, established substantive forums for dialogue, promotion of mutual learning, and the recognition and distribution of the value of mutual gains. The unions reported benefits of halted outsourcing, improved job security, more management respect, and more ability to influence managerial decisions. Management actors reported immediate improvement in company actors' perception of union rights and value, and recognition of the employees and unions as partners in the enterprise. Actors report a shift in the organization's culture from 'fighting, bossing, and grievance' to one of more listening, joint problemsolving, and cooperation. The company reports commercial value in examples of improved customer satisfaction, waste reduction, efficiency improvements, and social reputation. 
In the course of these accomplishments, which retain fragilities and uncertainties, there were and remain considerable obstacles, tensions and challenges. The following section is principally a descriptive depiction of difficulties. This picture enables the in-depth discussion of the analytical themes that follows.

\section{Tensions, difficulties and challenges}

Parties report scepticism, mistrust, wariness and risk. A non-company political actor recalls that managers who had 'been on the other side when the industrial strike frequency was high, were obviously sceptical at the beginning' (Political actor \#2). The unions similarly report reservation: 'We had union lawyers saying don't get into this. Don't do it ... There was mistrust absolutely everywhere' (Union actor \# 20). We focus first on union actors' responses to tensions and challenges, and then those of management.

Union actors report significant challenges in regard to management, other unions, and union members. A set of historical and habituated tensions within and between occupational unions within the partnership presented labour actors with a distinct challenge. Historical tensions between the larger and smaller unions of occupational groups whose interests are variously divergent have marked inter-union relations. A union leader reported: 'Entering into this sort of collaborative model is a minefield. The bigger union tends to set the pace. The employer deals with the bigger union because they represent more employees' (Union actor \#2). Another adds: 'There is competitive unionism and that's not likely to go away. That's just the reality. But in HIP we've all agreed to work collaboratively' (Union actor \#3).

Union actors report that working with other unions and company actors on HIP working groups has led to recognition of shared interests across occupational and divisional groups. Observable tensions and divergence remain between union members and union leaders who are highly engaged in the practicalities of the HIP processes. Traditional 
adversarial relations and behavioural expectations continue to influence attitudes and behaviour. A union organiser described a traditional 'mind-set' among his members: 'They are quite a cynical bunch. To this day, they say HIP was just used to cull numbers... They thought we're in the boss's back pocket... They didn't like the way that we were trying to work together.' (Union actor \#4). Another union organiser reports on member perceptions: 'It's really a fine line to keep your credibility with both parties...It's easier to show that you're fighting ...that you're doing the hard battles. They don't see the quietness of us working together on [an issue] and where we can create more value and more productivity so we have a better outcome [for workers].' (Union actor \#5).

Union actors report their perceptions of mixed behaviour among managers in regard to enacting HIP processes. These include their critical concerns that: 'There are a lot of managers that just see HIP as a means to achieving their bottom line ... It's all about efficiency and cost neutrality'. (Union actor \# 8). They reported continuing conflicts notably in some business units and occupational groups of traditional management-union relations: 'We've had a few brush ups [tense interactions]' (Union actor \#9).

A delegate reported on a conflictual set of issues that were put into the HIP process: 'Managers can be quite deceitful and try to manipulate the process to achieve an outcome they want. When we were in opposition to [issue X], management tried to shut down the group. They would absent themselves or be unavailable for the group meetings' (Union actor \#12). At the same time, in addition to these illustrations of continuing conflicts, traditional attitudes and historical habits, union actors report that 'there are managers that have listened to people, taken on their concerns and then actually acted on it. . . [Managers] who make you feel that you are on a level playing field, that it's not manager versus staff member' (Union actor \#15). There remain significant levels of misunderstanding of what the company's partnership and HIP is about. 'If you go back to the old days of what were called partnership 
models. It was secretive. Union bosses, you know, being mates with the employer bosses, and the workers got screwed' (Union actor \#23).

Managers similarly remarked on the legacy of tensions and habitual attitudes. A senior manager reported that prior to the partnership undertaking 'the concept of creating a strategic partnership with unions was anathema; we didn't even know what it was. They were alien to us ...' (Management actor \# 9). Managers, too, carry traditional identities, behaviours, and norm expectations among themselves and in relation to unions. These affect the practicalities of communicating and enacting HIP practices in the everyday organizational life of company operations across multiple sites. They report a tendency for managers to blame other managers for the obstacles to implementing HIP and utilising its gains. One reports: 'There are some general managers that will let it go down the path and then they hit a wall, and they just can't collaborate anymore. They pull back and say no, we're not doing this.' (Management actor \#10).

Some middle managers in business units feel tasked with key performance indicators (KPIs) that they would prefer to achieve by avoiding the time-taking HIP processes if they can. A consultant observes that an HIP session "will come undone because somebody is focused on efficiency, compliance, speed or cost' (External consultant \#3). A manager reports that for some colleagues 'past experiences have left a bad taste in your mouth' (Management actor \#18). Others noted common organizational behaviours of individuals endeavouring to utilise institutional changes for their own advantages. Some managers 'have got their own agenda, or they want a promotion and they'll say, how does this benefit me?' (Management actor \#1). They use HIP forums to gain personally favourable outcomes.

Both parties report on the tensions of gaining and sustaining personnel commitment to HIP, especially for staff who aren't provided with workload release incentives to participate in activities that are 'on top of my day job' (Management actor \#2). These fragilities affect the 
shaping and embedding of HIP institutions across the company. A further vulnerability factor occurs in the continuing unevenness of dispersion of HIP practices and behaviours through the company. Senior managers report: 'A lot of people haven't touched HIP yet' (Management actor \#4) and: 'There are some senior people who haven't got on board [with HIP]. And we're years down the track...' (Management actor \#10).

Uneven dispersion and perceptions among some personnel of their business unit or group being left out of HIP initiatives generates tensions between the apparently 'more privileged' participants. Some occupational and business units, who are wary of HIP, find ways to engage at arm's length only. Union actors reported similar concerns in regard to gaps in knowledge and experience across the company: 'What we've got at the moment is, managers right at the top who understand HIP, and are pushing for it, and the union delegates who have been involved in HIP so they know more than the middle managers. But they also know more than the members. So you've got holes, gaps... How do you get employees on the shop floor engaged?' (Union actor \#16). Some union delegates reported a sentiment amongst their peers that while the 'higher ups [managers and union leaders]' are 'enthused' and 'invested' in HIP, front line workers are much less convinced that HIP is leading to tangible improvements in their working lives. Company managers recognise that HIP needs to be 'more meaningful for unions and the workforce' and to 'include all workers every day' (Management actor \#9) across the company.

Fragilities arising from uneven familiarity with and use of HIP collaborative problem recognition and resolution, as well as its avoidance by some managers and employees, generate tenuousness of commitment, and risk of more and less advantaged employees in regard to participatory and collaborative processes and benefits. Variable development and intra-middle management tensions across business units and geographic regions present considerable challenges to sustaining the partnership. Nonetheless, respondents across the 
company report continuing interest and commitment to enacting and embedding the partnership undertaking. No-one wants to 'go back to the bad old days' (Union actor \#8). One union organiser emphasises that 'we want to make sure that it [partnership] is done as well as we can possibly do it', even if it may 'take years' (Union actor \#20).

\section{Capability and capacity development}

The HIP initiation among company and union leaders declared and promoted mutual recognition and legitimacy of parties. The steps from mutual recognition of interests to enacting mutual, collaborative engagement require substantive new learning among multiple organizational actors. It requires actor capability development and collective organizational capacity development. The data reveals that the institutional change toward a collaborative culture is a continually learned, in situ, craft. It is not a spontaneous learning; it requires effort: 'the pure hard grunt of it' (Union actor \#6). Actors report diverse learnings from how 'to get my head around this' (Management actor \#7) to collaborative analysis 'of what's going on in Hong Kong [division]...' (Union actor \#15).

They report their learning of a range of new skills. We focus here on social-cognitive learning and the capacity development enabled by facilitating expertise recognition and exchange. Actors report that the skills and competences parties need to participate in collaborative and partnership forums are more sophisticated than the skill sets required of more traditional union and management relations. These extend from communication skills to developing strategic thinking. Respondents reported that delegates to HIP forums needed basic skills to speak confidently especially to management actors sharing the table: 'to make an HIP workgroup successfully, you need to have people who aren't afraid to challenge the way things are done' (Management actor \#6). For many employees, that competence requires active learning and encouragement. 'A member in my current group was quite shy, reserved, 
and fearful of voicing his opinion in front of management. It's been great to see his transition' (Union actor \#21). They reported learning to see various aspects of an issue and understand consequences of proposals or interventions.

Managers recognized the need for participatory skill development among personnel. 'We realized that our delegates needed help. If we're going to ask them to have a seat at the table, we need to be able to provide tools and skills for them to do that' (Management actor \#5). Various training sessions continue to be provided including through the use of external consultants. All new recruits are given training in HIP, typically of two-days duration.

Respondents report that inclusion of workers closely involved in various company operations in decision-making adds to knowledge resources, skilled expertise application, and knowledge dispersion: 'the workers [on site] know how the processes work or not because they're working on them each day. They have all this institutional knowledge built up' (Union actor \#13). The HIP involvement facilitates the 'breaking through' of that expertise to inform decisions on productivity objectives as well as operational and work scheduling issues.

An employee delegate remarks: 'being on these HIP working parties, your mind grows and you develop interest' (Union actor \#9). They reported interest in developing strategic awareness of 'what's going on in the company'. Union organisers remarked that their involvement in substantive decision-making processes demanded that they had 'to step up for it'. 'It's quite a different capability set; an ability to strategically analyse situations and understand complex issues (Union actor \#21). 'I think that's how we build that platform to say, you know, we're a serious, genuine, switched on partner here' (Union actor \#15). At the same time, as a union organiser described it, the vast 'asymmetry of resource, knowledge and capability' between unions and the company, which meant the union 'couldn't keep up with the company's HIP goals and projects' results in many 'conflicts and frustrations' between the two parties' (Union actor \#5). 
Parties recognized the need for greater sharing and disclosure of information that was previously withheld. To facilitate and build collaborative relations personnel sharing in addition to knowledge expertise sharing as illustrated above is required. Actors report union and management information sharing behaviours, including the sharing of commercially sensitive financial information, forecasting models, data analysis procedures, future plans and anticipated problems. That involves, in the first instance, risk to management parties normally accustomed to guardedness and control of information in the presence of labour actors. Likewise, union actors must learn appropriate handling of company information. A delegate reported that she accepted that 'there's always going to be no-go zones for a business reason' (Union actor \# 28). The union, she states, accepts reasonable transparency on such issues.

All parties agree that disagreement is evidence of a 'robust' and 'diverse' partnership but emphasise the need to disagree in a mature and respectful manner. As one union organiser describes 'you disagree with people and you're strong in your opinions, but you don't let it get personal. And you keep the lines of communication open all the time. You might be disagreeing about one thing and threatening [something else]. But then you'll move onto the next topic in the conversation and be agreeing.' (Union actor, \#24). The collective valuing of the partnership means that during an ongoing disagreement peers from union and management will call the involved parties and 'tell them to cool off; give them some good advice on how to approach it' (Union actor \#24).

A manager illustrates in speaking about some issues that were 'behind the scenes, $a$ very big elephant in the room' and in and HIP working group. 'We broke down those obstacles and discussed them with union executives and members and then the company [executives]. We were then able to move forward. We identified the blockage and worked around it' (Management actor \#4). In HIP groups where such trust hasn't been developed, the 
process is ultimately stalled with 'everyone strategizing or thinking about what information the other party may be withholding' (Union actor \#21).

The efforts and learnings depicted here comprise the development of social and cognitive capabilities that enable capacity development for the partnership to be practically enacted throughout the company. Formerly adversarial actors learn skills and competencies to become partners and co-construct their particular organizational partnership. In addition, and lubricating that social capital, is the activation of moral capital.

\section{Moral capital activation}

Actors report they have learned how to 'disagree without being disagreeable', to not 'let past experiences tarnish future endeavours', to 'deal with the fear that [we] might lose,' to 'give something back in return to maintain the relationship...' to let inter-union conflicts 'start to disappear' and that the labour-management partnership relationship 'takes a lot of time' to work out. These learnings entail more than social-cognitive application of knowledge resources to the effort to build partnership. They entail activation of the latent resource of moral capital. That includes toleration, patience, mutual respect and, not least, trust. Employee trust in management is positively affected by employee voice practices (Holland, Cooper, Pyman, and Teicher, 2012). But mutual trust requires improved management trust in labour partners along with respect for their representative roles. Actors, both labour and management, report their putting up with uncertainty and ambiguity, their patience with frustrations and perseverance with obstacles. They report shifts of identity prejudices and chauvinism to altered recognition of others and the complexity of the organization in which they are employed. They also report their shift from mistrust to trust, from withholding to sharing.

None of these expressions and shifts comes easily to most people in an industrial context noted for historical aggravation and intransigence. A manager reports: 'Everyone said 
we do want it [the former status quo] to change'. But the company realised it had to take the first steps because the unions said 'we've been battered and bruised for quite a long time so you guys have to show you've got [the wherewithal]. It was all a bit scary.' (Management actor \#9).

As well as fear of the risk-taking, cross-party actors report the need to tolerate frustration with expectations and confusion, as one union leader describes: 'there's frustration... we went into this thinking we could achieve X, Y, Z. But it's so slow with [those] guys and we can't get what we want' (Union actor \#3). He elaborates on a particular situation in which 'People got quite agitated and upset [about X] and we had to say hold on... We're just going to have to work through this. It's a long march.' (Union actor \#3). Developing the collective stamina and endurance to work through frustrations and obstacles, as well as having a longer term commitment to the relationship, is an important resource to develop within and between parties.

Cross-party actors admit to initial scepticisms and judgements about each other. A senior manager reports his misrecognition of trade unions and suspicion of their legitimacy. He reflected that before the launch of the partnership undertaking that: 'We didn't give a damn about the unions. We showed no empathy to them, we didn't understand where they were coming from.' He reports that on working with a senior union leader he discovered 'it was like talking to another senior leader in an organisation and then, all of a sudden, I had to get to know [more about partnering with unions]' (Management actor \#9). A union leader reports an illustration of that shift bearing fruit in respect and mutuality that had not previously occurred in his thirty years of experience: 'No [executive] has ever sent me the types of emails that $[X]$ has sent just to say, 'pretty impressed with what you guys did on that' (Union actor \#3). Another union leader describes ongoing formal and informal conversations with senior company officers about expansive and complex issues 'like the future of work', 
and cites an instance when senior company executives 'gave us an hour and a half of their time just to listen to the union... what our challenges are... That would never happen [prior to HIP], they would've just said 'why waste our day?' (Union actor \#15). Such instances are suggestive of an openness to mutual learning and influencing that has been created through the partnership.

Cross-party respondents recognized that trust is a core element of their partnership. They reported their efforts to generate it. For a union actor, 'Sharing information, agreeing to disagree... When I'm right and you're wrong, that doesn't work; that's a barrier. But ...then you try and find ways to get closer' (Management actor \#4). A senior manager reports that in order to engage in relationship change with the aim of mutual transparency and sharing of operational and strategic content he needed to go beyond information disclosure. Building trust required more than rational exchange. He reports that he realized he needed to make 'some apologies on behalf of management [to unions and employees]. We realised that we'd been harsh and our leadership style had been unfair. We had to take responsibility for the fact that we had damaged relationships' (Management actor \#9). Likewise, a union organiser describes a trust-building occasion through his disclosure to the HIP leadership team that the union movement is actively wrestling with conflicting philosophies about the future of unionism, especially with regard to inter- and intra- union conflicts about engaging in partnership relationships.

Participants state that the vulnerability of such disclosures, while experienced as risk and criticised by some, is vital to building trust in the partnership. The risk-taking in sharing has subsequently fostered greater trust among parties that has opened paths to further development. It builds capability of understanding and mutual recognition. As one delegate reports, 'When they're open with you with information and they actually say to you in an honest environment 'this is the problem for us, if you do that', I can look at both sides now' 
(Union actor \#14). A union delegate reported an example of improved relationship connections and trust that had occurred through working on HIP committees that had a spillover effect for other (non-HIP) matters. An employee 'was going through a disciplinary procedure. I rang up the manager and I said, hey look, can you give me a feel for this? And she [explained]. Several years ago that would have been unheard of' (Union actor \#23).

That illustration of new trust between the parties indicates the role of that resource in drawing out of rich tacit knowledge among the parties for application to finding mutually agreeable solutions to organizational and employment relations problems. Senior managers and union officials are observed and reported to engage in collective reflection on the state of the partnership relationship and seek behavioural adjustments to evolve the relationship. Trustful interactions and co-participation in forums to address issues also enables identity expansiveness and agility. A delegate reflects on her opening up: 'the first thing I used to say was no, no, no!... Now I'm a lot less combative.' Among her first learnings was to become more 'appreciative' in her relationships. 'I'm a lot more understanding of the organization'. It has made me realise that we-especially our [occupational] group of people-we're very stuck in the past.' (Union actor \#11).

In the process of practising these all-party competencies, actors undergo a shift and expansion of their traditional organizational identities, and an ability to move between multiple identities. Respondents speak of: 'I'm a different sort of person now...' 'I see things differently now', 'we're all employees...' and, 'it's no longer them and us'. Union organisers in particular spoke of 'taking one hat off and putting another hat on' (Union actor \#23) in their work, particularly when they moved between activities, or between non-partnership companies. The role of an organiser in collaborative efforts expands to include the traditional 'advocate' role and also 'facilitator', 'mediator' and 'problem-solver' roles. The organisers are well aware of the 'fine lines' that become 'a lot more blurred with HIP' (Union actor 
\#22), as they try to represent their members and advance organisational processes. For example, one organiser reflects upon a situation in which he was assisting with the formation of a company policy document. He caught himself questioning 'hang on, why am I helping the company write this policy? You guys should be doing this. This is not my role. But at the same time I'm thinking no, this is my role too within this [HIP] environment'. (Union actor \#24) Actors note that moving between different roles can have 'exhaustive' effects and can confuse members who might doubt their 'integrity' (Union actor \#23). These new complexities comprise ongoing collective reflections among union teams.

Managers similarly express features of a shift in conventional, or neo-liberal, managerialist role identity. Managers face normative pressures from the broader business environment of MNC management. These include common managerialist prerogative approaches popularized by US business schools over recent decades. A manager illustrates one of these international pressures in respect to personnel recruitment. 'People come and say "what on earth are you doing? Everybody else out there is beating up their unions ... why don't you have a strategy that gets rid of your unions?" (Management actor \#9). Those criticisms in some business circles require affected managers to navigate those pressures alongside pressures from other sceptics distrustful of the company's and trade unions' collaborative effort. Participatory management, they find, requires a more fluid and complex identity construction. Through their joint participation in HIP forums union actors similarly report their recognition of managers' pressures from the wider international environment. A union leader notes that 'most international management people don't operate in this paradigm, right?' (Union actor \#3). They are more cognisant and respectful of those pressures and aware of mutual responsibilities for collaborative relationships.

In sum, the development of personnel qualities through drawing on moral resources enables them to see wider horizons of interests and strive to accommodate them. Cross-party 
engagement in complex organizational processes, alongside personnel's operational roles, draws on moral resources that in turn generate a new, collective moral capacity. The significant reforms and facilitation of new ways of working together across the organization are consolidating into positive co-dependencies. A breach of the agreement or failure of commitment to HIP would now constitute, as a manager put it, 'a painful separation'.

\section{Discussion}

The achievements of the venture to forge institutional change toward a strategic partnership are recognized and welcomed by a majority of respondents. New institutions for regulating employment relations including con-joint forums for participation in significant decision-making have been established. These accomplishments are accompanied by similarly recognized persistent tensions and tough challenges. For some, the partnership remains more experimental than robustly established as the company's now normal way of conducting its industrial relations and organizing its production processes. For others, 'there is no going back to the bad old days'. Actors from all parties emphasise that the collaboration is not ' $a$ sort of nirvana'; it is a work in progress. The fragility of the venture, we propose, is nonetheless accompanied by revelation of significant potency for further capability building in forging collaborative relations. That potency, we propose, results from the social and moral capital that the partnership both draws on and generates through its concrete enactment. Its motif of 'management and unions walking into the unknown together', as a senior manager describes the living out of the partnership, has mobilized under-utilized resources and generated more complex competencies for economic and social utility in the company.

Institutions are typically sticky and hard to change. Industrial relations institutions are likely especially prone to retentiveness (Crouch, 2014) as they entail multiple sets of norms, identities, and political histories. Some researchers contend that in regard to labourmanagement partnerships 'the state, employers and unions remain locked into a status quo 
that militates against sustainable mutuality' (Dobbins and Dundon, 2017, p. 530). In addition, in liberal market economies partnership efforts ineluctably occur in conditions of intense international competitiveness. Their immense pressures prompt many to conclude that enlightened management and unions will not be enough to support partnerships (Delaney and Haworth, 2016; Kochan, 2008). Calls for stronger state regulation to support these undertakings are frequently made. That support should undoubtedly help. But even in a context of government encouragement of partnership relations, as occurs in New Zealand, the outcomes of any undertaking may ultimately be determined by the collective accomplishments of on-site actors.

Kochan (2016) remarks that partnerships are prone to crisis and disappointment. A key factor in the resilience of the, to date, eighteen-year Kaiser-Permanente partnership has been the ability of multiple parties to apply the 'tools of the partnership' to address the challenges as they arise. Among those tools, Kochan (2016) suggests, are the skills and leadership of key actors. We contend that in addition to those resources of social capital, the 'tools of partnership' include generating and utilizing what we call moral capital. Moral capital includes toleration of ambiguity, uncertainty, and frustration; resources of patience, mutual respect, trust, sharing and openness. Our study demonstrates the effortful development of social-cognitive skills among cross-party personnel in negotiating the practicalities of the partnership. These capabilities are fostered through deliberate learning and training seminars for personnel (including all new recruits). Importantly, we stress, capacity is also being built through the activation of moral resources.

Moral capital is a concept derived from Durkheimian sociology's emphasis on social rules and normative regulation. It is similar to Bourdieu's (1992) concepts of social and cultural capital, which refer to the 'sum of resources', in addition to economic capital, that individuals and groups accrue through their interaction in networks of relationships and 
shared values. While Bourdieu regarded social capital as a powerful resource of elites, other theorists, notably Coleman (1988) and Field (2008), emphasise that diverse actors accrue and utilize social capital. In regard to economic relations, attention to the everyday deployment of social capital among people in market and workplace relations reveals the social embeddedness of economic action. It also reveals the moral dimensions that are often ignored in economic analysis (Etzioni, 1988).

Giddens (1991) and Sztompka (1999) respectively single-out trust for its vital role in all social relations. They theorize trust as a moral, value-laden, quality. Further philosophical and sociological discussion of trust is beyond our purposes here. Our sketch is intended to underscore the value of trust as a resource, and accomplishment. We propose, furthermore, that attention to trust's cognate phenomena of patience, reciprocity, positive affect, and interpersonal sharing may yield further insight into the construction and sustenance of partnership collaboration.

This study reveals Company A's initiation of the partnership undertaking arose from a more or less shared recognition among cross-party actors of the institutional fatigue of congealed adversarialism. The initiative for institutional innovation put in place clear structural arrangements for voice expression and skilled participation. They sought, implicitly, to enact a collaborative pluralism (Bray et al., 2015). The data reveals that the favourable new structures and conditions were welcome but insufficient to making it work. That requires the ‘moral dimension' (Etzioni, 1988) and moral resource application as we have elaborated.

Much industrial and employment relations research has under-addressed the complexity of identities, interests, and moral aspirations of people at work. It has tended to assume, like much organizational research, that a moral economy and moral expression are quietly, invisibly woven into everyday organizational life. Deployment of moral capital ought to be expected of mature adults working in rational, purposive organizations. Yet it is in the 
breach that the vitality and fragility of these resources is exposed. Legalistic HRM practices, unilateral managerial control and adversarial trade unions can be functional. But, as Company A's partnership undertaking recognized from the outset, those routines can inhibit development of other qualities in organizational and employment life that generate a mutual socio-economic benefit in the longer run.

A labour-management partnership in liberal market economies is conducted in a context of asymmetrical formal power relations. It is an ineluctably tensionful affair. It is therefore no surprise that mistrust, scepticism and uneven involvement are evident in this undertaking. What is noteworthy is that the partnership has also facilitated participatory power (Casey et al. 2016) that yields complex new capacities that alter formal dynamics and shift relationships toward a sophisticated collaboration. The development of socio-cognitive skills and activation of moral capital have created a local power to develop new shared norms and habits. The shaping and enactment of new shared norms generate capacities among company actors and unions to utilize human resources of sociality and cognitive and political skills to create a unique, particular partnership among themselves. They have created collective capacity to address problems and issues that the discussants have agreed to recognize and commit to resolution.

These in turn have enabled some actors to shift identity attachments - to expand their more encamped identities. Skilled professional and trade employees in the application of their expertise to production and organizational tasks demonstrate their self-identities as not only that of employees with an employment relationship to be protected by their union. Their expression of expertise as organizational members stimulates an interest in organizational life and quality of their collective work. Managers similarly identify as organizational actors and employees alongside union actors. HIP processes of joint problem-solving and mutual recognition enable employees and managers to express a more complex identity and 
multifaceted interests. Their organizational interests include but extend beyond the employment relationship and into the shaping of the organizational economy.

A further point must be noted. The extensive involvement of external consultants and facilitators in capacity building indicates the ongoing need for support and development of key partnership behaviours. We observed that the neutral and mutually respected consultants play a considerable role in generating the multifaceted skills, competences, and qualities of partners. Their visibility in socio-cognitive skills is readily apparent. But they also foster the activation of moral capital through their encouragement, modelling, and careful inclusiveness. We recommend further close empirical research on these third party actors in partnership sustainability.

\section{Conclusion}

The significant programme of formal and normative institutional reform, and behavioural change on the part of company actors, managers, employees and unions, observed in this study is, after five years, still in its early days. The positive outcomes we identify are incremental and fragile. Robust embedding and normalisation throughout the organization remains to be achieved. The broadly welcome achievements, not least the cessation of adversarial dispute, attrition of some tenacious misconceptions among the various key parties, and sustained pursuit of the aspirations of partnership, are accompanied by significant challenges. These problems pose risks of regression and failure with subsequent risk of longer term avoidance of socio-cultural innovation in employment and organizational relations. Nonetheless, the advances in participatory practices and actors' persistent efforts to make them work in addressing workplace and employment issues indicate that the path to partnership as sophisticated and multifaceted collaboration in this company has opened. Firm strategic choice and actors' moral action are significant. 
Setting up and enacting HIP systems and forums has opened the arena of engagement. Along with voice expression in problem-solving, the processes enable interest adjudication and interest expansion. Their action produces new resources for productivity and quality of organizational life and behaviour. Reaching beyond conventional identities as employees, unionists, managers and executives toward discovery of shared interests, from productivity to quality of working life, poses a radical, new collaborative pluralism that accommodates shifts and nuances and multi-directional power relations. Skilled, collaborative actors can harness these currents to craft a democracy of responsibility for organizational life, and company governance. To draw on a Durkheimian understanding, partnership is a moral economy as much as it is a material one. It is locally, collectively generated and enacted.

Partnership can be formally decreed but its enactment is a continual aspiration, a laborious craft toward political and social mutuality and recognition of plural interests. Its moral embedding in the organization and sustained legitimacy over time proposes, ultimately, responsible collaboration in all and highest levels of governance of the company. 


\section{References}

Ackers, P. (2014) Rethinking the Employment Relationship: A neo-pluralist critique of British Industrial Relations orthodoxy. International Journal of Human Resource Management, 25, 2608-2625.

Ackers, P. and Payne, J. (1998). British Trade Unions and Social Partnership: Rhetoric, Reality and Strategy, International Journal of Human Resource Management 9(3): $529-549$.

Appelbaum, E. and Hunter, L. (2005). 'Union Participation in Strategic Decisions in Corporations' in Freeman, R.; Hersch, J.; Mishel, L. (eds.), Emerging Labor Market Institutions for the Twenty-first Century, Chicago: University of Chicago Press.

Badigannavar, V. and Kelly, J. (2011). Partnership and organizing: An empirical assessment of two contrasting approaches to union revitalization in the UK. Economic and Industrial Democracy 32(1) 5-27. DOI: 10.1177/0143831X10365925.

Barbalet, J. (2009 A characterization of trust, and its consequences. Theory and Society vol.38: 367-382.

Barry, M. and Wailes, N. (2004). Contrasting Systems? 100 Years of Arbitration in Australia and New Zealand. Journal of Industrial Relations 46(4): 430-447.

Batt, R. (2004). 'Who benefits from teams: comparing workers, supervisors, managers', Industrial Relations, 43: 183-212.

Bélanger, J. and Edwards, P. (2007). The conditions promoting compromise in the workplace. British Journal of Industrial Relations, 45 (4): 713-34.

Blumberg, P. (1968) Industrial Democracy. The Sociology of Participation. London: Constable. 
Boxall, P. and Macky, K. (2009) Research and Theory on High-Performance Work Systems: Progressing the High-Involvement Stream. Human Resource Management Journal, $19,3-23$.

Bourdieu, P. (1992) The Logic of Practice. Stanford, CA: Stanford University Press.

Bray, M., Macneil, J. and Stewart, A. (2017). Cooperation at Work. Sydney NSW: Federation Press.

Bray, M., Budd, J. and Macneil, J. (2015). The many meanings of cooperation in the employment relationship and their implications.17th ILERA World Congress, South Africa. Available online https://www.ilera2015.com/dynamic/full/IL87.pdf

Butler, P., Glover, L. and Tregaskis, O. (2011). "When the going gets tough" . . : recession and the resilience of workplace partnership. British Journal of Industrial Relations, 49 (4): $666-687$.

Casey, C., Fiedler, A., Fath, B. (2016). The European Company (SE): Power and participation in the multinational corporation. European Journal of Industrial Relations, Vol.22 (1): 73-90.

Coleman, J. (1988), Social capital in the creation of human capital. American Journal of Sociology vol.94: S95-S120.

Crouch, C. (2014). 'The Neo-liberal turn and the implications for labour,' in Wilkinson, A.; G. Wood and R. Deeg (eds.) The Oxford Handbook of Employment Relations: Comparative Employment Systems. Oxford: Oxford University Press.

Cutcher-Gershenfeld, J. Brooks, D. and Mulloy, M. (2015). Inside the Ford-UAW Transformation: Pivotal events in valuing work and delivering results. Cambridge MA: MIT Press. 
Danford, A. and Richardson, M. (2016). 'Why partnership cannot work and why militant alternatives can: historical and contemporary evidence'. In S. Johnstone and A. Wilkinson (eds), Developing Positive Employment Relations: International Experiences of Labour Management Partnership, pp. 49-76. Basingstoke: Palgrave.

Danford, A., Richardson, M., Stewart, P., Tailby, S., and M., Upchurch (2005). Partnership and the High Performance Workplace, Basingstoke: Palgrave Macmillan.

Deakin, S., Hobbs, R., Konzelmann, S. and Wilkinson, F. (2005). Working Corporations: Corporate Governance and Innovation in Labour-management Partnerships in Britain, in M. Stuart and M. Martinez Lucio (eds) Partnership and Modernisation in Employment Relations, pp. 63-82. Abingdon: Routledge.

Delaney, H. and Haworth, N. (2016). 'Battling in a bleak environment: the New Zealand context for partnership', in Johnstone, S. and Wilkinson, A. (eds.) Developing Positive Employment Relations. London: Palgrave Macmillan.

Dobbins, T. and Dundon, T. (2017). The chimera of sustainable labour-management partnership. British Journal of Management, 28: 519-533.

Dobbins, T. and Gunnigle, P. (2009). Can voluntary workplace partnership deliver sustainable mutual gains? British Journal of Industrial Relations 47(3): 546-70.

Etzioni, A. (1988). The Moral Dimension. Toward a new economics. New York: The Free Press.

Farr, D., Laird, I., Lamm, F., \& Bensemann, J. (2019). Talking, listening and acting: Developing a conceptual framework to explore 'worker voice' in decisions affecting 
health and safety outcomes. New Zealand Journal of Employment Relations, 44(1): $79-100$.

Field, J. (2008). Social Capital, London: Routledge.

Geary, J. and Trif, A. (2011). Workplace partnership and the balance of advantage: A critical case analysis. British Journal of Industrial Relations, 49: s44-s69.

Getman, J. (2010). Restoring the Power of Unions, New Haven: Yale University Press.

Giddens, A. (1991). Modernity and Self-Identity, Stanford CA: Stanford University Press.

Glover, L., Tregaskis, I. and Butler, P. (2014). Mutual Gains? The workers' verdict: A longitudinal study. International Journal of Human Resource Management, 25(6): $895-914$.

Godard, J. (2004). A critical assessment of the high-performance paradigm. British Journal of Industrial Relations, 42, 349-378.

Guest, D. and Peccei, R. (2001). Partnership at work: mutuality and the balance of advantage. British Journal of Industrial Relations. 39 (2): 207-236.

Haynes, P. Marchington, M. and Boxall, P. (2007). Workplace union-management partnership in, Peter Holland, Julian Teicher, Richard Gough (eds.). Employment Relations in the Asia-Pacific Region: Reflections and New Directions. Abingdon: Routledge.

Haynes, P., Boxall, P. and Mckay, K. (2005). Non-union voice and the effectiveness of joint consultation in New Zealand. Economic and Industrial Democracy 26(2):229-256. 
Haynes, P. and Allen, M. (2001). Partnership as union strategy: A preliminary evaluation. Employee Relations, 23(2): 164-87.

Heckscher, C. (1988). The New Unionism: Employee involvement in the changing corporation. New York: Basic Books.

Hirschhorn, L. (1984). Beyond Mechanization: Work and technology in a post-industrial age. Cambridge MA: MIT Press.

Holland, P., Cooper, B., Pyman, A. and Teicher, J. (2012). Trust in management: the role of employee voice arrangements and perceived managerial opposition to unions. Human Resource Management Journal 22(4): 377-91.

Johnstone, S. (2015). 'The case for workplace partnership'. In S. Johnstone and P. Ackers (eds). Finding a voice at work: New perspectives on employment relations. pp.153174. Oxford: Oxford University Press

Johnstone, S. and Wilkinson, A. (2017). The Potential of Labour-Management Partnership: A longitudinal case analysis. British Journal of Management, (3): 554 - 570.

Johnstone, S., Ackers, P. and Wilkinson, A. (2009). The British Partnership Phenomenon: a ten year review. Human Resource Management Journal, 16 (3): 260-275.

Kochan, T. (2016). 'The Kaiser Permanente labour management partnership'. In S. Johnstone and A. Wilkinson (eds), Developing Positive Employment Relations: International Experiences of Labour Management Partnership, pp. 249-280. Basingstoke: Palgrave.

Kochan, T., Eaton, A.; McKersie R. and Adler, P. (2009). Healing Together: The LabourManagement Partnership at Kaiser Permanente, Ithaca, NY: Cornell University Press. 
Kochan, T. and Osterman, P. (1994). The Mutual Gains Enterprise: Forging a Winning Partnership among Labor, Management, and Government. Cambridge, MA, Harvard University Press.

Kochan, T. A., Adler, P. S., McKersie, R. B., Eaton, A. E., Segal, P., and Gerhart, P. (2008). The potential and precariousness of partnership: the case of the Kaiser Permanente labor management partnership. Industrial Relations: A Journal of Economy and Society, 47(1), 36-65.

Lansbury, R. (1980). Democracy in the Workplace. Melbourne: Longman Cheshire.

McAndrew, I., F. Edgar, A. Geare and M. Ballard (2010). Employment relations ideologies and cooperative partnership approaches to bargaining: The New Zealand perspective. Korean Journal of Industrial Relations, 20 (1): 53-80.

McAndrew, I. (2006). Employers, unions, and workplace partnerships in New Zealand. New Zealand Journal of Employment Relations, 31(3): 51 - 65.

Macneil, J., Haworth, N. and Rasmussen, E. (2011). Addressing the productivity challenge? Government-sponsored partnership programs in Australia and New Zealand. International Journal of Human Resource Management, 22(8): 3814-3830.

Oxenbridge, S. and Brown, W. (2002) The two faces of partnership?: An assessment of partnership and co-operative employer/trade union relationships, Employee Relations, (24): 3, 262-276.

Piore, M. and Sabel, C. 1984). The Second Industrial Divide. NewYork: Basic Books.

Ramsay, H. (1977). Cycles of Control: Worker participation in sociological and historical perspective, Sociology, 11, 481-506. 
Ramsay, H., Scholarios, D. and Harley, B. (2000). Employees and high-performance work systems: testing inside the black box, British Journal of Industrial Relations, 38: 3, $501-531$

Rasmussen, E. (2009). Employment Relations in New Zealand. Auckland: Pearson Education.

Samuel, P. and Bacon, N. (2010). The contents of partnership agreements in Britain 19902007. Work, Employment and Society, Volume 24(3): 430-448

Stuart, M. and Martinez Lucio, M. (2005). Where next for partnership? In Martinez Lucio, M. and Stuart, M. (eds.) Partnership and Modernisation in Employment Relations. London: Routledge.

Sztompka, P. (1999). Trust: A Sociological Theory. Cambridge University Press.

Taylor, P. and Ramsay, 1998. Unions, partnership and HRM: Sleeping with the enemy? International Journal of Employment Studies, 6(2): 115-143.

Thompson, P. and van den Broek, D. (2010). Managerial control and workplace regimes: an introduction. Work, Employment and Society, 24(3): 1-12

Townsend, K.; Wilkinson, A.; Burgess, J. (2014). Routes to partial success: collaborative employment relations and employee engagement. The International Journal of Human Resource Management 25 (6): 915 - 930.

Wallace, M. (1989). Brave New Workplace: Technology and work in the New Economy. Work and Occupations, 16 (4): 363-392.

Wood, S. (2010). 'High Involvement Management and Performance' in Wilkinson et al. (eds). The Oxford Handbook of Participation in Organizations. Oxford: Oxford University Press. 